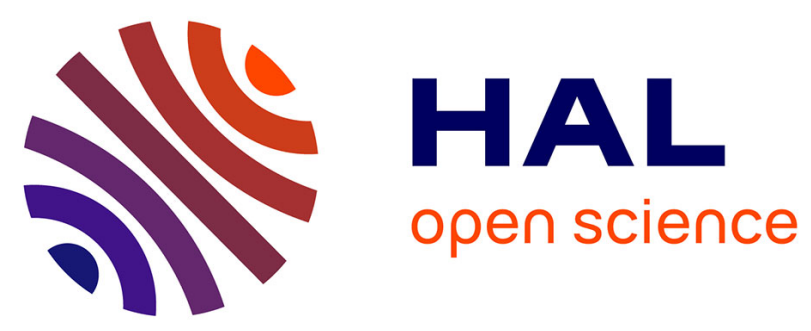

\title{
Benthic macrofauna and sediment reworking quantification in contrasted environments in the Thau Lagoon
}

Eric Duport, Franck Gilbert, Jean-Christophe Poggiale, Karine Dedieu, Christophe Rabouille, Georges Stora

\section{To cite this version:}

Eric Duport, Franck Gilbert, Jean-Christophe Poggiale, Karine Dedieu, Christophe Rabouille, et al.. Benthic macrofauna and sediment reworking quantification in contrasted environments in the Thau Lagoon. Estuarine, Coastal and Shelf Science, 2007, 72, pp.522-533. 10.1016/j.ecss.2006.11.018 . hal-00734368

\section{HAL Id: hal-00734368 \\ https://hal.science/hal-00734368}

Submitted on 21 Sep 2012

HAL is a multi-disciplinary open access archive for the deposit and dissemination of scientific research documents, whether they are published or not. The documents may come from teaching and research institutions in France or abroad, or from public or private research centers.
L'archive ouverte pluridisciplinaire HAL, est destinée au dépôt et à la diffusion de documents scientifiques de niveau recherche, publiés ou non, émanant des établissements d'enseignement et de recherche français ou étrangers, des laboratoires publics ou privés. 


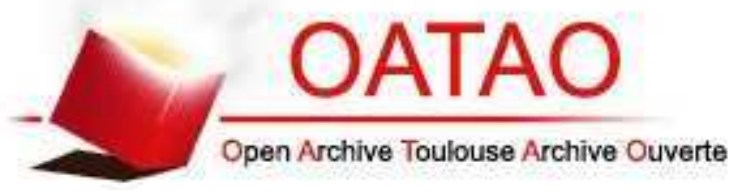

\section{Open Archive Toulouse Archive Ouverte (OATAO)}

OATAO is an open access repository that collects the work of Toulouse researchers and makes it freely available over the web where possible.

This is an author-deposited version published in: http://oatao.univ-toulouse.fr/ Eprints ID: 6094

To link to this article: doi:10.1016/j.ecss.2006.11.018 http://dx.doi.org/10.1016/j.ecss.2006.11.018

To cite this version: Duport, Eric and Gilbert, Franck and Poggiale, JeanChristophe and Dedieu, Karine and Rabouille, Christophe and Stora, Georges Benthic macrofauna and sediment reworking quantification in contrasted environments in the Thau Lagoon. (2007) Estuarine, Coastal and Shelf Science, vol. 72 ( $\mathrm{n}^{\circ} 3$ ). pp. 522-533. ISSN 0272-7714 


\title{
Benthic macrofauna and sediment reworking quantification in contrasted environments in the Thau Lagoon
}

\author{
E. Duport ${ }^{\text {a }}$, F. Gilbert ${ }^{\text {a,* }}$, J.-C. Poggiale ${ }^{\text {a }}$, K. Dedieu ${ }^{\text {b }}$, C. Rabouille ${ }^{\text {b }}$, G. Stora ${ }^{\text {a }}$ \\ ${ }^{a}$ Laboratoire de Microbiologie, Géochimie et Ecologie Marines (UMR CNRS 6117), COM, Université de la Méditerranée, \\ Campus de Luminy, Case 901, F-13288 Marseille Cedex 09, France \\ ${ }^{\mathrm{b}}$ Laboratoire des Sciences du Climat et de l'Environnement (LSCE), UMR CNRS-CEA, Domaine du CNRS, Bât. \\ 12, avenue de la Terrasse, F-91198 Gif sur Yvette, France
}

\begin{abstract}
As part of the Microbent-PNEC Program: "Biogeochemical processes at the water-sediment interface in eutrophicated environment", the aim of this work was to specifically investigate and quantify the relationships between macrobenthos and sediment reworking in the Thau Lagoon in order to provide information on the potential contaminant distribution and movements at the water-sediment interface. In order to achieve this, three cores were sampled at two stations (in the central part of the Thau Lagoon and near the shellfish farming zone) in the Thau Lagoon, in December 2001, April 2002, August 2002, January 2003 and May 2003. On the basis of quantification of macrobenthos and sediment reworking, evidence is provided of: (1) similar sediment mixing intensities for different species composition at the two stations; (2) the major role of functional bioturbation groups (e.g., biodiffusors and gallery-diffusors) modulated by seasonal variability on sediment mixing; (3) an increase of intensity in summer suggesting potentially different patterns of redistribution, bioaccumulation and chemical fate (e.g., speciation) of deposited contaminants.
\end{abstract}

Keywords: macrobenthos; bioturbation; functional biodiversity; sediment reworking; luminophores; Thau Lagoon

\section{Introduction}

This research is one component of the Microbent-PNEC Program: "Biogeochemical processes at the water-sediment interface in eutrophicated environment". The program focuses on the development of improved understanding and microscale quantification of reactive processes and contaminant fluxes at the water-sediment interface and through benthic organisms in the Thau Lagoon (Mediterranean Sea) where intensive shellfish farming has been developed (Gangnery et al., 2003).

Investigations focused on (1) biogeochemical processes (diagenetic filter) that control the environmental settings; (2) biotic or abiotic processes inducing contaminant transfers

\footnotetext{
* Corresponding author.

E-mail address: gilbert@com.univ-mrs.fr (F. Gilbert).
}

at the water-sediment interface; (3) numerical modeling of these processes.

All active bioturbation processes such as construction of biogenic structures, irrigation of burrows, sediment mixing and production of fecal pellets influence the distribution and the fate of organic matter and pollutants at the water-sediment interface and within the sediment (e.g., Lee and Swartz, 1980; Gérino et al., 1995; Gilbert et al., 1996; Stoeck and Kröncke, 2001). Quality and intensity of sediment reworking generated by macrofauna are modified by changes in population characteristics, e.g., biomass, density, functional groups (François et al., 1999; Gérino et al., 1999; Sandnes et al., 2000), and environmental factors (Mortimer et al., 1999; Orvain and Sauriau, 2002; Ouellette et al., 2004).

The key objective of this study was to quantify the relationships between macrobenthos and sediment reworking in two contrasted environments of the Thau Lagoon and bring 
information on the potential contaminant distribution and movements at the water-sediment interface.

\section{Material and methods}

\subsection{Study site}

The study was carried out in the Thau Lagoon, a shallow $75 \mathrm{~km}^{2}$ lagoon located on the French Mediterranean coast (Fig. 1). The Thau Lagoon is the largest shellfish breeding area in Europe (Soletchnik et al., 2002) and yearly produces about 35000 tons of shellfish (Hamon and Tournier, 1981; Gangnery et al., 2003). This lagoon is connected to the sea through the narrow channels of Sète and receives freshwater mostly from the north shore. The Vène and Pallas rivers are the major streams representing $43 \%$ of the total watershed $\left(280 \mathrm{~km}^{2}\right)$. The measurements were carried out at two stations: station C4 (N 4324.018, E $3^{\circ} 36.703^{\prime} ; \sim 8 \mathrm{~m}$ depth), in the central part of the lagoon and station $\mathrm{C} 5\left(\mathrm{~N} \mathrm{43^{ \circ }} 25.994^{\prime}, \mathrm{E}\right.$ $3^{\circ} 39.657^{\prime} ; \sim 8 \mathrm{~m}$ depth), located inside the eastern shellfish farming zone.

\subsection{Sampling and analytical methods}

In December 2001, April 2002, August 2002, January 2003 and May 2003, sediments from both stations were collected by scuba diving using PVC cores (i.d. $10 \mathrm{~cm}, 30 \mathrm{~cm}$ height). Three sediment cores at each station were incubated in a tank at in situ

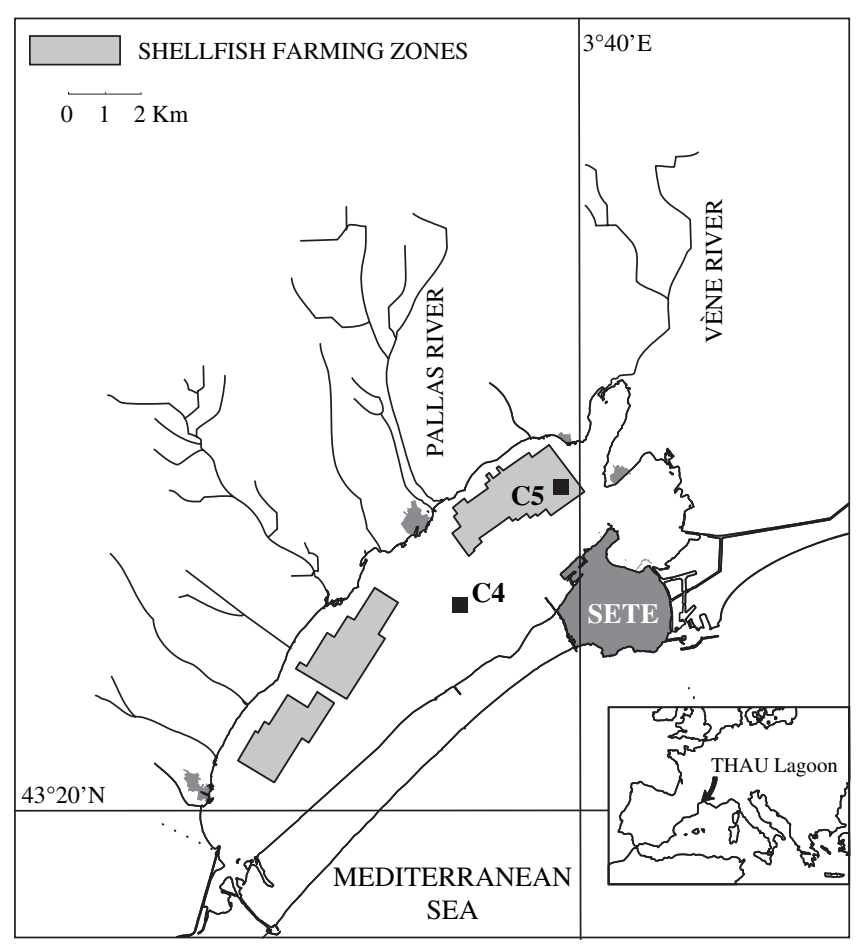

Fig. 1. Sampling site and locations of the two stations in the Thau Lagoon (station C4 in the central part of the lagoon and station C5 near the shellfish farming area). temperature under a water flow system allowing three complete turnovers of respective aerated bottom water each day in each core. In order to quantify the sediment reworking activity in the sediments the overlying water was removed and fluorescent luminophores ( $2 \mathrm{~g} ; 160-200 \mu \mathrm{m}$ diameters) were deposited at the sediment surface (Gérino, 1990). Then, the water flow system was re-activated.

After nine days of sediment-water incubation, the sediment cores were sliced in $0.5-\mathrm{cm}$ layers from 0 to $3 \mathrm{~cm}$ depth, and then in 1-cm-thick sections from $3 \mathrm{~cm}$ down to $15 \mathrm{~cm}$ depth. Sediment slices were sieved through a $250 \mu \mathrm{m}$ mesh to remove macrofauna (preserved in $4 \%$ buffered formaldehyde with Rose Bengal for species identification) from sediment particles.

Sediments were then freeze-dried, gently crushed to powder and homogenized. Sediment subsamples were taken for luminophore counting under UV light using a digital camera (Olympus C-2500L) and an image analysis software (image $\mathrm{J}$; http://rsb.info.nih.gov/ij/) (Gilbert et al., 2003).

Part of the intact samples (first sediment layer) was used to determine sediment granulometry. This was performed with the Mastersizer diffraction laser granulometer. The method used was based on the one described by Woolfe and Michibayashi (1995) but without sonicating the samples. Using this instrument, it was possible to measure particle size $(<1 \mathrm{~mm})$ of each sample which was dispersed in water. Samples were measured with at least $8 \%$ obscuration under moderately high pump and stirrer settings.

During the same sampling times, oxygen penetration depths were measured in situ by polarographic oxygen microelectrodes coupled to a microprofiler (Unisense ${ }^{\circledR}$ ) mounted on a tripodal frame positioned on the sea-floor. Oxygen fluxes were calculated using the diffusive oxygen uptake or flux $\left(J_{\mathrm{O}_{2}}\right)$ at the SWI following Fick's First Law. For more information about oxygen sediment profiling and flux calculation, see Dedieu et al. (2007).

\subsection{Data analysis}

\subsubsection{Macrofaunal community}

Classical analytical and synthetic methods (Clarke and Warwick, 2001) were used to assess the temporal dynamics of benthic assemblages at stations $\mathrm{C} 4$ and C5. Interpretation of results was based on faunal data expressed as species richness, density, dominance and biomass.

Homogenous groups of stations were singled out by cluster analysis (Primer; Clarke and Warwick, 2001) applied to a similarity matrix obtained by the coefficients of Sorensen (Sorensen, 1948) and Bray-Curtis (Bray and Curtis, 1957), which are, respectively, a qualitative coefficient based on the presence-absence of the species and a quantitative coefficient based on their dominance.

In order to determine the main factors responsible for the composition and the structure of the assemblages according to time, a factorial correspondence analysis (FCA) was carried out (Benzecri et al., 1973). The advantage of this method is that both the lines and columns of a contingency table can be represented on the same projection planes. 
In order to interpret the signification of the different axes, correlations (Coefficient of Spearman) were calculated from the results obtained by the FCA, between the ordination of variables on the adopted axes and the percentages of different biological indicators present in samples (Vincent, 1981). These indicators can be either specific to an original assemblage (characteristic species) or to one or several grain size fractions (silt, sand, gravel, etc.). In other cases, they can mark particular environmental conditions such as sediment instability or pollution (perturbation bio-indicator), or they can have no particular ecological requirements (wide ecological range species) (Pérès and Picard, 1964; Picard, 1965; Pearson and Rosenberg, 1978; Pérès, 1982). The trophic and functional composition based on the bioturbation mode of assemblages have been determined using indications provided by Coull (1977), Fauchald and Jumars (1979), Word (pers. comm.), and Gérino et al. (2004).

According to Blake and Grassle (1994), organisms for which the identification was uncertain (e.g., juveniles, anterior fragments, etc.) were used only for density and biomass measurements and were not included in similarity and multivariate analysis calculations.

\subsubsection{Sediment reworking data modeling}

The reaction-diffusion type model used in this paper to describe luminophore redistribution following macrofaunal reworking is based on the general diagenetic equation (Berner, 1980):

$\frac{\partial Q}{\partial t}=\frac{\partial}{\partial z}\left(D_{\mathrm{b}} \frac{\partial Q}{\partial z}\right)+R(Q)$

where $Q$ is the quantity of the tracer, $t$ is the time, $z$ is the depth, $D_{\mathrm{b}}$ is the apparent biodiffusion coefficient, and $R(Q)$ is the non-continuous displacement of tracer. The term $R(Q)$ is defined as follows:

$R(Q(z, t))=\left\{\begin{array}{l}\frac{r}{z_{2}-z_{1}} \int_{0}^{x_{1}} Q(x, t) \mathrm{d} x \text { if } z \in\left[z_{1} ; z_{2}\right] \\ -r Q(z, t) \text { if } z \in\left[0 ; z_{1}\right] \\ 0 \text { if } z>z_{2}\end{array}\right.$

where $z_{1}$ and $z_{2}$ define the upper and lower limits of the tracer redistribution, $x$ and $z$ are depth variables and $r$ is the biotransport coefficient that is the percentage of tracer that left the $\left[0, x_{1}\right]$ deposit and was redistributed in the $\left[z_{1}, z_{2}\right]$ layer. The redistribution of tracer between $z_{1}$ and $z_{2}$ and the disappearance of tracer from the $0-z_{1}$ layer are, respectively, described by Eqs. (2a) and (2b). Eq. (2c) indicates that no tracer movement occurs below $z_{2}$.

This displacement term was originally exemplified in a model describing gallery-diffusion of macrofaunal reworking (François et al., 2002). This biological reworking process describes the diffusive-like mixing of particles in the region of intense burrowing activity and the rapid transport of organic and inorganic material from the upper sediment layers to the lower regions of reworking (i.e. 'biotransport').

According to the experimental conditions, the following initial conditions were used:

$Q(z, 0)= \begin{cases}Q_{0} & \text { if } z \in\left[x_{1} ; x_{2}\right] \\ 0 & \text { else }\end{cases}$

where $\left[x_{1} ; x_{2}\right]$ is the tracer deposit layer.

Finally, a zero-flux Neuman boundary condition was considered:

$\frac{\partial Q}{\partial z}(0, t)=\lim _{z \rightarrow+\infty} \frac{\partial Q}{\partial z}(z, t)=0$

The application of this bioturbation model to tracer redistributions allowed the quantification of two particle mixing coefficients: an apparent biodiffusion coefficient $D_{\mathrm{b}}$ and a biotransport coefficient $r$. The biodiffusion coefficient $D_{\mathrm{b}}$ takes into account the diffusion-like transport due to the activity of the organisms. We assume that the actual concentration dependent diffusion of tracers is negligible. The biotransport coefficient $(r)$ represents a non-local mixing pattern associated with a biologically induced transfer of particles from one place to another in a discontinuous pattern (i.e. a noncontinuous transport; Boudreau, 1986; Meysman et al., 2003).

\subsubsection{Analysis of variance}

For each station, we studied the temporal changes of macrobenthic organism densities, biomass, and the sediment reworking coefficients $\left(D_{\mathrm{b}}\right.$ and $r$ ), using analysis of variance. As time is not an independent factor, data were then evaluated using repeated-measures way ANOVA (Zar, 1998). Bartlett's test ( $\alpha=0.05$ ) was employed to test a priori the homogeneity of variance. Heteroscedastic data were transformed (square root transformation for biomass and $r$, and $\log$ transformation for density and $D_{\mathrm{b}}$ ) to obtain homogeneity of variances.

\section{Results}

\subsection{Macrofauna}

\subsubsection{Species richness, density and biomass}

For each station, species richness was measured over time (Fig. 2). Species richness was quite stable over time in station C4 from 36 (December 2001 and May 2003) to 44 (April 2002, August 2002 and January 2003). On the other hand, changes in species richness over time were more marked in station C5, ranging from 21 (May 2003) to 40 (April 2002). Although species richness was higher in station $\mathrm{C} 4$ than in station C5, their changes over time were similar.

Changes of organism density over time, for both stations, are shown in Fig. 3. At station $\mathrm{C} 4$, densities ranged from $17244 \pm 2727$ (December 2001) to $78149 \pm 10702{\text { ind } \mathrm{m}^{-2}}^{-2}$ (mean $\pm \mathrm{SD} ; n=3$ ) (January 2003). At station C5, the lowest and highest densities measured were $8069 \pm 3388$ (January 2003) and $35880 \pm 7391$ ind $\mathrm{m}^{-2}$ (mean $\pm \mathrm{SD} ; n=3$ ) (April 


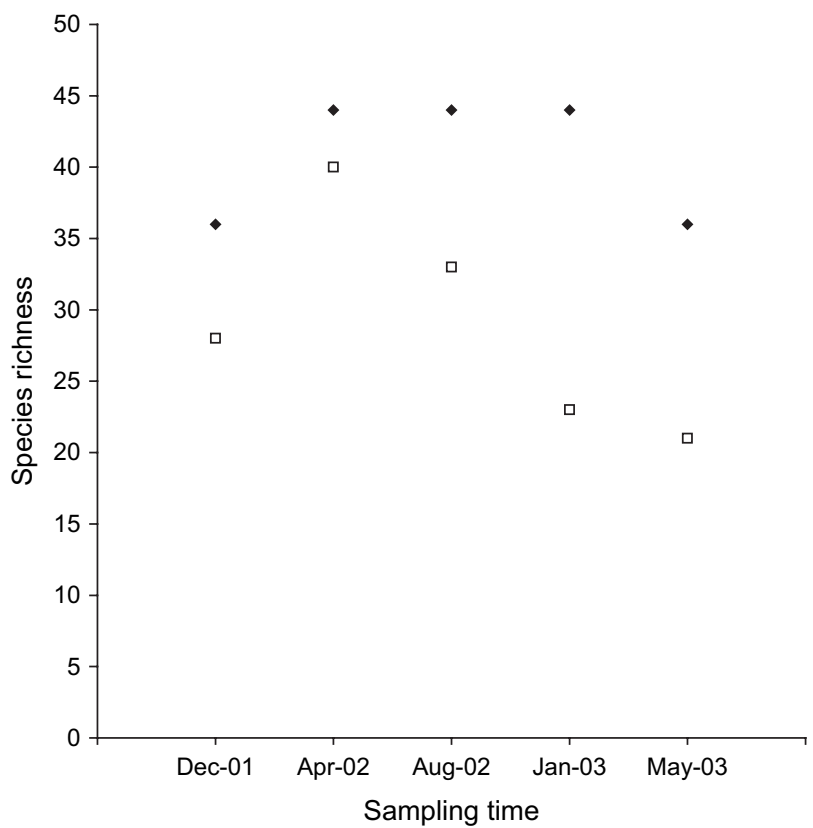

Fig. 2. Change in species richness of macrobenthic organisms in sediments from the central part of the Thau Lagoon (C4: full symbol) and near the shellfish farming zone (C5: open symbol), over time. Data are mean $\pm \mathrm{SD}$ $(n=3)$.

2002). The interaction "stations $\times$ time" was found significant $(F=14.96, P<0.001)$, indicating important dissimilarities in density of the faunal assemblages between the two stations.

The total community wet biomass, as presented in Fig. 4, varied between 200 and 500 wet $\mathrm{g} \mathrm{m}^{-2}$ at station $\mathrm{C} 4$. On the other hand, it was less stable over time at station C5 showing extreme

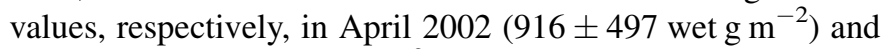
May $2003\left(63 \pm 37\right.$ wet $\left.\mathrm{g} \mathrm{m}^{-2}\right)($ mean $\pm \mathrm{SD} ; n=3)$. Significant differences (ANOVA) in biomass were found with time $(F=7.22, P<0.01)$ but not between stations probably due to high spatial variability between replicates within stations.

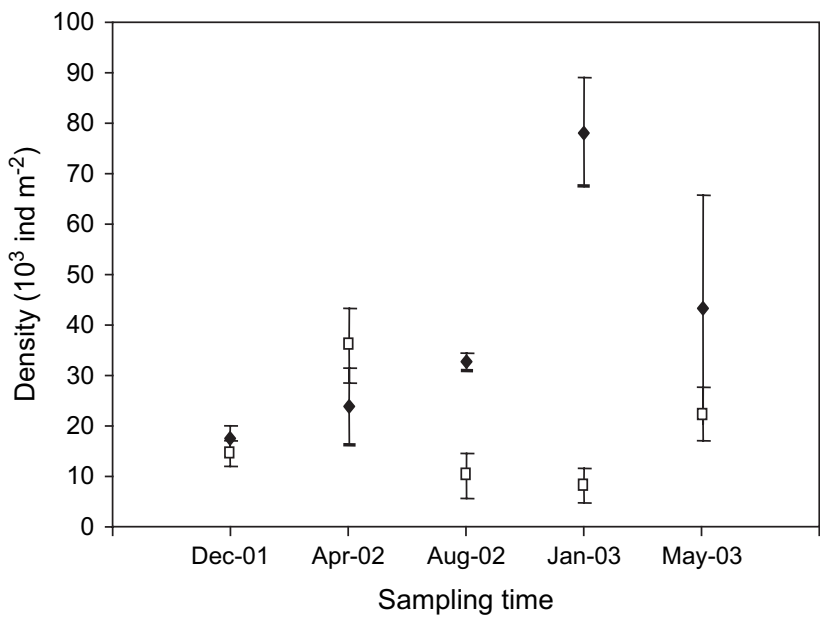

Fig. 3. Density of macrobenthic organisms (ind $\mathrm{m}^{-2}$ ) in sediments from the central part of the Thau Lagoon (C4: full symbol) and near the shellfish farming zone (C5: open symbol), for the different sampling times. Data are mean $\pm \mathrm{SD}(n=3)$

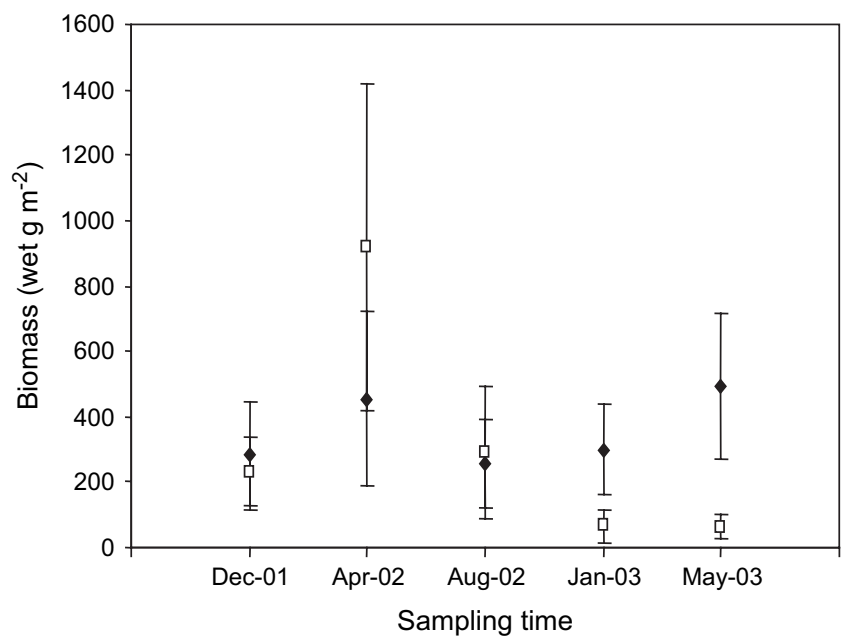

Fig. 4. Total macrobenthic community biomass (wet $\mathrm{g} \mathrm{m}^{-2}$ ) in sediments from the central part of the Thau Lagoon (C4: full symbol) and near the shellfish farming zone (C5: open symbol), for the different sampling times. Data are mean $\pm \mathrm{SD}(n=3)$.

\subsubsection{Affinity of the assemblages}

From a qualitative point of view, clusters obtained from Sorensen similarity indicate three groups of samples (Fig. 5; top). The first and second groups are, respectively, composed of December 2001, January 2003 and May 2003 and of April 2002 and August 2002 station C5 samples. The third group corresponds to station $\mathrm{C} 4$ samples, showing a different species composition between the two stations. The strong similarity (close to 60\%) inside the third group of station $\mathrm{C} 4$ characterizes a low change in species composition with time. On the other hand, for station C5, similarities lower than $40 \%$ inside the first group and between the first and second group show a marked variability in species composition with time.

From a quantitative point of view, the cluster patterns resulting from Bray-Curtis similarity analysis are composed of five groups of samples (Fig. 5; bottom): (1) C4-December 2001, and C4- and C5-April 2002; (2) C4-August 2002, -January 2003 and -May 2003; (3) C5-August 2002; (4) C5December 2001 and -January 2003; (5) C5-May 2003. The low intra and inter-group similarities $(<50 \%)$ demonstrate a different species structuration both within stations and over time (Table 1).

Assemblages being different between the two stations, the following analyses of stations C4 and C5 have been separated.

\subsubsection{Relation between macrofauna and environmental factors}

At station $\mathrm{C} 4$, the factorial correspondence analysis was carried out on a contingency table crossing 78 species against 15 samples. The first three axes explain $69 \%$ of the total data variability (axis $1=42 \%$, axis $2=14 \%$, axis $3=12 \%$ ). The results are given in Figs. 6 and 7, where the plotted projection plane is illustrated by the factorial planes I-II and I-III, of all the samples and species presenting the strongest absolute and relative contributions. 




Bray-Curtis Similarity

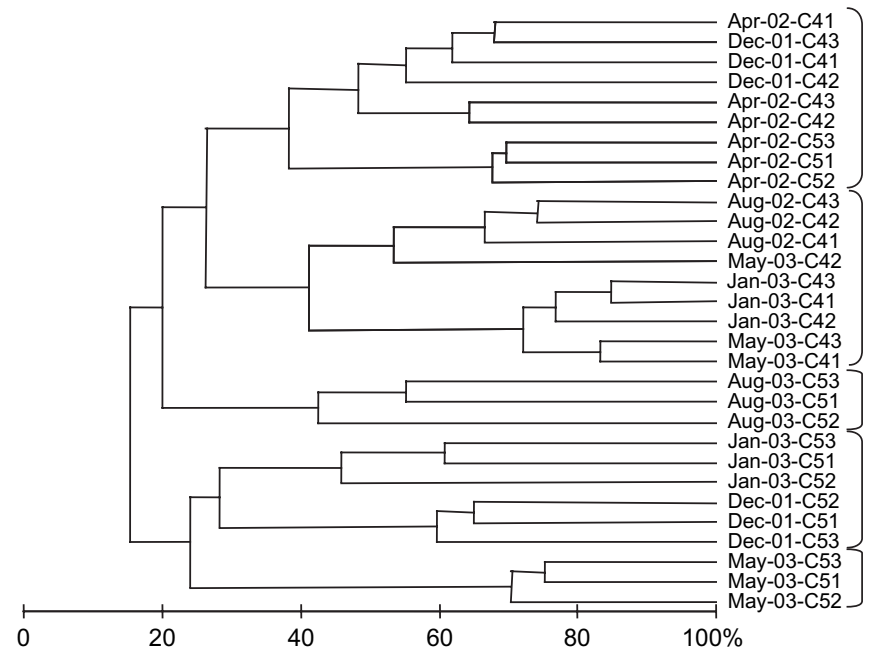

Fig. 5. Dendrogram of Thau samples clustered with Sorensen's index (top) and Bray-Curtis index (bottom) and group average sorting. Sample code: sampling time, station name and replicate number, e.g., December 2001-C41 means replicate 1 of station 4 (central part of the Thau Lagoon) in December 2001.

The first axis separates essentially December 2001 and April 2002 samples located on the negative side of the first axis from the January 2003 and May 2003 samples (Figs. 6 and 7). One notes a significant positive correlation between the ordination of the variables along axis 1 and the percentage of surface deposit feeders $(r=0.96)$ and a negative correlation with the percentage of sub-surface deposit feeders present in the different samples $(r=-0.84)$.

Axis 2 contrasts December 2001 and August 2002 samples and one April 2002 sample with the other samples (Fig. 6). No significant correlation was evidenced. The species contributing to the creation of the second axis, however, are essentially vagile species, with suspension feeders dominant in April 2002 samples compared to the other samples. Moreover, in April 2002, the highest biomasses measured for similar organism densities to December 2001 and August 2002 indicate a mature condition of the community specifically in April 2002.

Axis 3 contrasts more particularly the August 2002 samples and one May 2003 sample with the other samples (Fig. 7). Significant correlations exist between the ordination of variables along the third axis and (1) the percentage of tolerant muddy species $(r=-0.93)$, and (2) the percentage of particle fraction between 4 and $63 \mu \mathrm{m}(r=0.77)$. The increase in tolerant muddy species, which can develop when only a small fraction of silt is present, associated with a decrease of silt along the third axis demonstrates the influence of the granulometry changes on the assemblage dynamics.

At station $\mathrm{C} 5$, the factorial correspondence analysis was carried out on a contingency table crossing 61 species against 15 samples. The first three axes explain $49 \%$ of the total data variability (axis $1=25 \%$, axis $2=16 \%$, axis $3=7 \%$ ). The first axis separates essentially May 2003 samples located on the negative side of the first axis from the others (Figs. 8 and 9). One can note significant negative correlations between the ordination of the variables along axis 1 and the percentage of perturbation bio-indicators $(r=-0.99)$, and the percentage of surface deposit feeders $(r=-0.84)$, but a positive correlation with the percentage of suspension feeders present in the different samples $(r=0.84)$. This first axis is especially marked by a perturbation factor.

Axis 2 contrasts the December 2001 samples located on the negative side of the axis essentially from April 2002 and May 2003 samples (Fig. 8). A negative correlation is apparent between the ordination of variables along the second axis and (1) the percentage of minuticolous species $(r=-0.80)$ and (2) the percentage of silt between 4 and $63 \mu \mathrm{m}(r=-0.85)$. Minuticolous species are more particularly present in substrates presenting silt or fine sand without coarse sand or gravel (Picard, 1965). The distribution of samples along the second axis could be related to a change in the granulometry distribution with time marked by the presence, in April 2002 and May 2003, of coarser particles in the surface layer compared to December 2001.

Axis 3 contrasts the August 2002 and May 2003 samples located on the negative side of the axis with the other samples (Fig. 9). One notes a significant negative correlation $(r=-0.70)$ between samples and the dominant sedimentary fraction. In August 2002 and May 2003, higher proportions of sand were measured in the sediments compared to December 2001, April 2002 and January 2003. Moreover, in August 2002, more species characteristic of muddy sand in sheltered areas and fine sand assemblages were found in the sediments showing a flourishing state of the community at this time. Again, the distribution of samples along this axis could be related to a change in the granulometry distribution with time.

\subsection{Sediment reworking}

\subsubsection{Tracer profiles}

More than $99 \%$ of the deposited luminophores were detected within the first $5 \mathrm{~cm}$. From $1.1 \pm 0.7 \%$ to $52.3 \pm 25.6 \%$ 
Table 1

Dominant and subdominant species (Sanders et al., 1980) in the central part of the Thau Lagoon (station C4) and near the shellfish farming zone (station C5), for the different sampling times. Dom.: dominance (\%); Den.: density (ind $\mathrm{m}^{-2}$ ); class (C: Crustacean, M: Mollusc, O: Oligochaeta, P: Polychaeta)

\begin{tabular}{|c|c|c|c|c|c|c|c|c|c|c|c|c|c|c|c|c|c|c|c|c|}
\hline & \multicolumn{4}{|c|}{ December 2001} & \multicolumn{4}{|c|}{ April 2002} & \multicolumn{4}{|c|}{ August 2002} & \multicolumn{4}{|c|}{ January 2003} & \multicolumn{4}{|c|}{ May 2003} \\
\hline & Class & Species & Dom. & Den. & Class & Species & Dom. & Den. & Class & Species & Dom. & Den. & Class & Species & Dom. & Den. & Class & Species & Dom. & Den. \\
\hline \multicolumn{21}{|l|}{ Station C4 } \\
\hline Dominant & $\mathrm{O}$ & $\begin{array}{l}\text { Tubificidae } \\
\text { ind. }\end{array}$ & 18.7 & 3218 & $\mathrm{C}$ & $\begin{array}{l}\text { Microdeutopus } \\
\text { anomalus }\end{array}$ & 13.2 & 3122 & $P$ & $\begin{array}{l}\text { Sphaerosyllis } \\
\text { hystrix }\end{array}$ & 25.92 & 8502 & $\mathrm{P}$ & $\begin{array}{l}\text { Exogone } \\
\text { gemmifera }\end{array}$ & 39.2 & 30597 & $\mathrm{P}$ & $\begin{array}{l}\text { Sphaerosyllis } \\
\text { hystrix }\end{array}$ & 37.6 & 16235 \\
\hline \multirow[t]{11}{*}{ Subdominant } & $\mathrm{P}$ & $\begin{array}{l}\text { Paradoneis } \\
\text { lyra }\end{array}$ & 16.2 & 2786 & $\mathrm{O}$ & Tubificidae ind. & 8.9 & 2113 & $P$ & $\begin{array}{l}\text { Mediomastus } \\
\text { californiensis }\end{array}$ & 12.9 & 4227 & $\mathrm{P}$ & $\begin{array}{l}\text { Sphaerosyllis } \\
\text { hystrix }\end{array}$ & 30.4 & 23728 & $\mathrm{P}$ & $\begin{array}{l}\text { Exogone } \\
\text { gemmifera }\end{array}$ & 22.3 & 9606 \\
\hline & $P$ & $\begin{array}{l}\text { Staurocephalus } \\
\text { rudolphi }\end{array}$ & 11.1 & 1921 & $\mathrm{P}$ & $\begin{array}{l}\text { Exogone } \\
\text { gemmifera }\end{array}$ & 7.3 & 1729 & $P$ & $\begin{array}{l}\text { Prionospio } \\
\text { malmgreni }\end{array}$ & 12.3 & 4035 & $\mathrm{P}$ & $\begin{array}{l}\text { Prionospio } \\
\text { malmgreni }\end{array}$ & 6.8 & 5284 & $\mathrm{P}$ & $\begin{array}{l}\text { Mediomastus } \\
\text { californiensis }\end{array}$ & 7.3 & 3170 \\
\hline & $\mathrm{P}$ & $\begin{array}{l}\text { Exogone } \\
\text { gemmifera }\end{array}$ & 9.5 & 1633 & $\mathrm{P}$ & Paradoneis lyra & 6.5 & 1537 & $\mathrm{P}$ & Paradoneis lyra & 8.1 & 2642 & $\mathrm{P}$ & $\begin{array}{l}\text { Mediomastus } \\
\text { californiensis }\end{array}$ & 4.7 & 3650 & $\mathrm{P}$ & $\begin{array}{l}\text { Prionospio } \\
\text { malmgreni }\end{array}$ & 7 & 3026 \\
\hline & $\mathrm{P}$ & $\begin{array}{l}\text { Sphaerosyllis } \\
\text { hystrix }\end{array}$ & 6.1 & 1057 & $\mathrm{P}$ & $\begin{array}{l}\text { Staurocephalus } \\
\text { rudolphi }\end{array}$ & 6.3 & 1489 & $P$ & $\begin{array}{l}\text { Staurocephalus } \\
\text { rudolphi }\end{array}$ & 6.9 & 2258 & & & & & $\mathrm{P}$ & $\begin{array}{l}\text { Pseudoleiocapitella } \\
\text { fauveli }\end{array}$ & 6 & 2594 \\
\hline & $P$ & $\begin{array}{l}\text { Magalia } \\
\text { perarmata }\end{array}$ & 4.8 & 817 & $\mathrm{P}$ & $\begin{array}{l}\text { Sphaerosyllis } \\
\text { hystrix }\end{array}$ & 5.5 & 1297 & $P$ & Paraleiocapitella sp. & 4.1 & 1345 & & & & & & & & \\
\hline & M & $\begin{array}{l}\text { Venerupis } \\
\text { aurea }\end{array}$ & 4.8 & 817 & $\mathrm{C}$ & $\begin{array}{l}\text { Ampelisca } \\
\text { typica }\end{array}$ & 5.1 & 1201 & & & & & & & & & & & & \\
\hline & & & & & M & Abra alba & 4.9 & 1153 & & & & & & & & & & & & \\
\hline & & & & & $\mathrm{P}$ & $\begin{array}{l}\text { Tharyx } \\
\text { multibranchii }\end{array}$ & 4.7 & 1105 & & & & & & & & & & & & \\
\hline & & & & & $\mathrm{M}$ & Loripes lacteus & 4.5 & 1057 & & & & & & & & & & & & \\
\hline & & & & & $\mathrm{P}$ & Grubea limbata & 4.3 & 1009 & & & & & & & & & & & & \\
\hline & & & & & $\mathrm{P}$ & $\begin{array}{l}\text { Heteromastus } \\
\text { filiformis }\end{array}$ & 4.1 & 961 & & & & & & & & & & & & \\
\hline \multicolumn{21}{|l|}{ Station C5 } \\
\hline \multirow[t]{2}{*}{ Dominant } & $P$ & $\begin{array}{l}\text { Tharyx } \\
\text { multibranchii }\end{array}$ & 28.7 & 4083 & $\mathrm{P}$ & $\begin{array}{l}\text { Exogone } \\
\text { gemmifera }\end{array}$ & 15.1 & 5428 & $P$ & $\begin{array}{l}\text { Modiolus } \\
\text { adriaticus }\end{array}$ & 10.1 & 1009 & $\mathrm{P}$ & Capitella sp.5 & 29.8 & 2402 & $\mathrm{P}$ & $\begin{array}{l}\text { Capitella } \\
\text { capitata }\end{array}$ & 29.2 & 6484 \\
\hline & & & & & & & & & $P$ & $\begin{array}{l}\text { Prionospio } \\
\text { malmgreni }\end{array}$ & 10.1 & 1009 & $\mathrm{P}$ & $\begin{array}{l}\text { Exogone } \\
\text { gemmifera }\end{array}$ & 23.2 & 1873 & $\mathrm{P}$ & Capitella sp. 3 & 27.7 & 6148 \\
\hline \multirow[t]{8}{*}{ Subdominant } & $P$ & Capitella sp.5 & 25 & 3554 & $\mathrm{O}$ & Tubificidae ind. & 12.9 & 4611 & $\mathrm{P}$ & $\begin{array}{l}\text { Sphaerosyllis } \\
\text { hystrix }\end{array}$ & 9.6 & 961 & $\mathrm{O}$ & Tubificidae ind. & 11.9 & 961 & $\mathrm{P}$ & $\begin{array}{l}\text { Staurocephalus } \\
\text { rudolphi }\end{array}$ & 13.4 & 2978 \\
\hline & $\mathrm{P}$ & $\begin{array}{l}\text { Armandia } \\
\text { cirrosa }\end{array}$ & 13.2 & 1873 & $\mathrm{C}$ & Tanaïs cavolinii & 12.6 & 4515 & M & Loripes lacteus & 9.1 & 913 & $\mathrm{P}$ & Capitella sp. 3 & 9.5 & 769 & $\mathrm{P}$ & Capitella sp.5 & 11.5 & 2546 \\
\hline & $P$ & Capitella sp.4 & 4.7 & 672 & $\mathrm{P}$ & $\begin{array}{l}\text { Microdeutopus } \\
\text { anomalus }\end{array}$ & 6.7 & 2402 & $\mathrm{P}$ & Capitella sp.5 & 7.2 & 720 & $\mathrm{C}$ & $\begin{array}{l}\text { Ampelisca } \\
\text { typica }\end{array}$ & 5.4 & 432 & $\mathrm{C}$ & $\begin{array}{l}\text { Ampelisca } \\
\text { typica }\end{array}$ & 4.1 & 913 \\
\hline & $P$ & $\begin{array}{l}\text { Mediomastus } \\
\text { californiensis }\end{array}$ & 4.1 & 576 & $\mathrm{P}$ & Capitella sp.3 & 5.4 & 1921 & $\mathrm{P}$ & $\begin{array}{l}\text { Tharyx } \\
\text { multibranchii }\end{array}$ & 6.7 & 672 & & & & & & & & \\
\hline & & & & & $\mathrm{P}$ & Capitella sp.5 & 5 & 1777 & M & Venerupis aurea & 6.7 & 672 & & & & & & & & \\
\hline & & & & & $P$ & $\begin{array}{l}\text { Notomastus } \\
\text { latericeus }\end{array}$ & 5 & 1777 & $\mathrm{C}$ & Iphinoe tenella & 5.8 & 576 & & & & & & & & \\
\hline & & & & & & & & & M & Abra alba & 4.8 & 480 & & & & & & & & \\
\hline & & & & & & & & & $P$ & $\begin{array}{l}\text { Magalia } \\
\text { perarmata }\end{array}$ & 4.8 & 480 & & & & & & & & \\
\hline
\end{tabular}






Fig. 6. Central part of the Thau Lagoon (C4). Results of the correspondence analysis in factorial planes I-II, mixture of cores and species. Sample code: sampling time and replicate number, e.g., December 2001-1 means replicate 1 in December 2001.

(mean $\pm \mathrm{SD}, n=3$ ) of tracers were buried below the sediment surface layer, with the highest values measured in August 2002 for both stations (Fig. 10). Luminophore distributions exhibited exponentially decreasing profiles from the surface



Fig. 7. Central part of the Thau Lagoon (C4). Results of the correspondence analysis in factorial planes I-III, mixture of cores and species. Sample code as in Fig. 6.

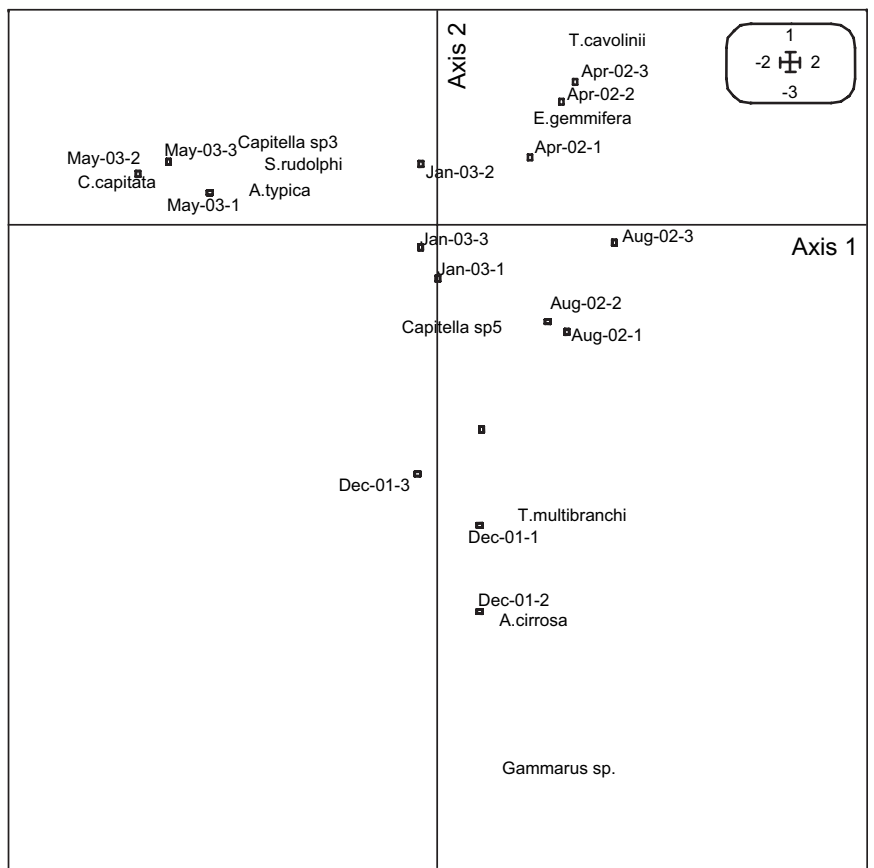

Fig. 8. Near the shellfish farming zone (C5). Results of the correspondence analysis in factorial planes I-II, mixture of cores and species. Sample code as in Fig. 6.

sediment down to $2 \mathrm{~cm}$ depth followed by deeper particle burying. For each station, the tracer maximum burying depth constantly varied with time $(5-14.5 \mathrm{~cm}$ depth) without showing any evident time pattern.

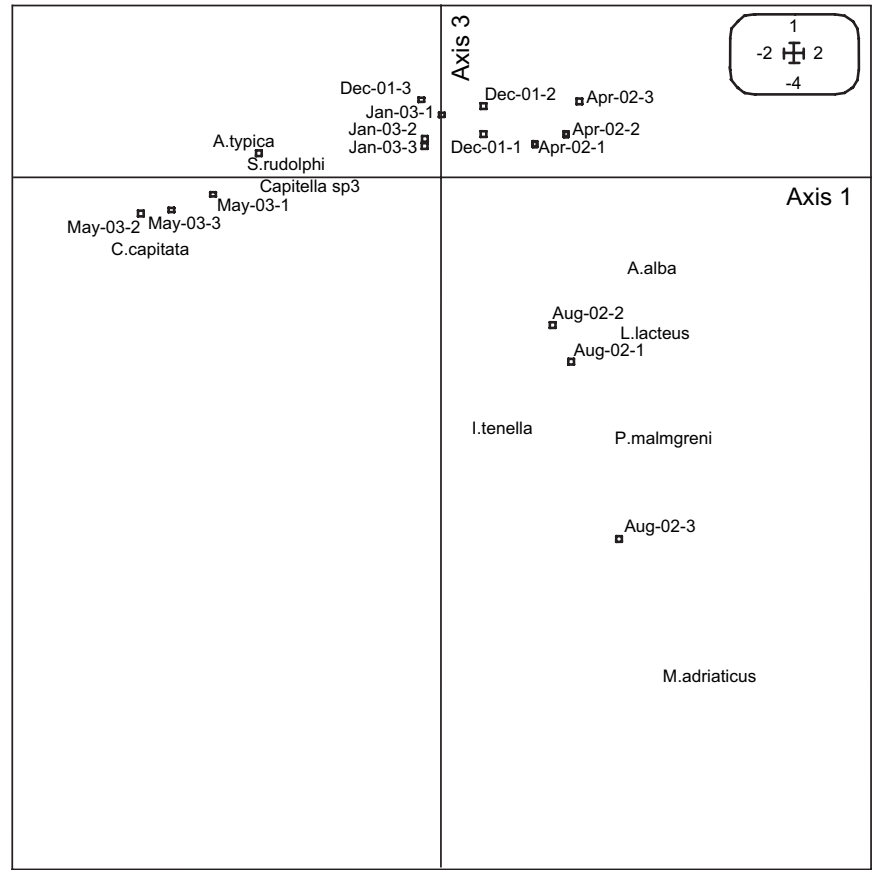

Fig. 9. Near the shellfish farming zone (C5). Results of the correspondence analysis in factorial planes I-III, mixture of cores and species. Sample code as in Fig. 6. 

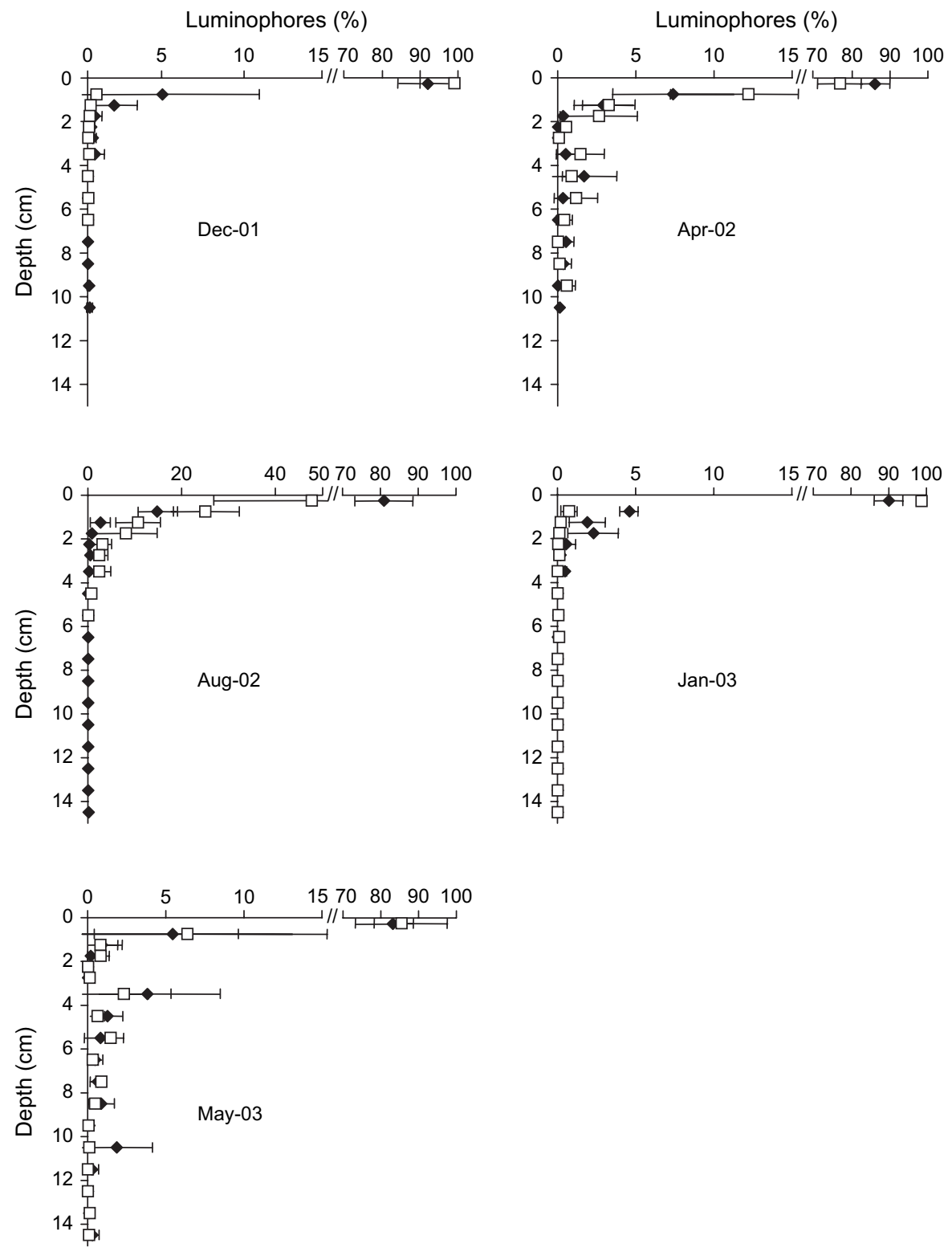

Fig. 10. Luminophore depth profiles in sediments from the central part of the Thau Lagoon (C4: full symbol) and near the shellfish farming zone (C5: open symbol), for the different sampling times. Data are expressed in relative percentage of total tracers (mean $\pm \mathrm{SD}, n=3$ ).

\subsubsection{Sediment reworking coefficients}

For both stations, the quantification of sediment reworking activity showed that the mixing of deposited tracers in the sedimentary column could be explained by both continuous $\left(D_{\mathrm{b}}\right)$ and non-continuous transport $(r)$. Mean $D_{\mathrm{b}}$ ranged, respectively, at stations C4 and C5, between 0.7 (April 2002) and 2.9 (August 2002) $\mathrm{cm}^{2} \mathrm{y}^{-1}$, and between 0.5 (December 2001) and 3.1 (August 2002) $\mathrm{cm}^{2} \mathrm{y}^{-1}$ (Fig. 11A). The highest $r$ values were also measured in August 2002 for the two stations (C4: $8.3 \pm 4.7 \mathrm{y}^{-1}$; C5: $11.1 \pm 0.7 \mathrm{y}^{-1}$; mean $\pm \mathrm{SD} ; n=3$ ) while the other biotransport coefficients were found to be close in December 2001, April 2002 and January 2003 and intermediate in May 2003 (Fig. 11B).

Significant differences in biodiffusive-like transport $\left(D_{\mathrm{b}}\right)$ with time $(F=8.33, P<0.001, \mathrm{ddl}=4)$ were highlighted.
This was not the case for non-continuous transport $(r)$. For both mixing coefficients, no significant differences were found between the two stations.

\section{Discussion and conclusion}

\subsection{Macrofauna}

Both stations are constituted by a classical mixture of muddy sand in sheltered areas and fine sand assemblages (Picard, 1965; Guelorget et al., 1994; Deslous-Paoli et al., 1998). At station C4 (in the central part of the Thau Lagoon), however, characteristic fine sand species are dominant while station C5 (near the shellfish farming zone) is dominated by species characteristic of the muddy sand in sheltered areas. 

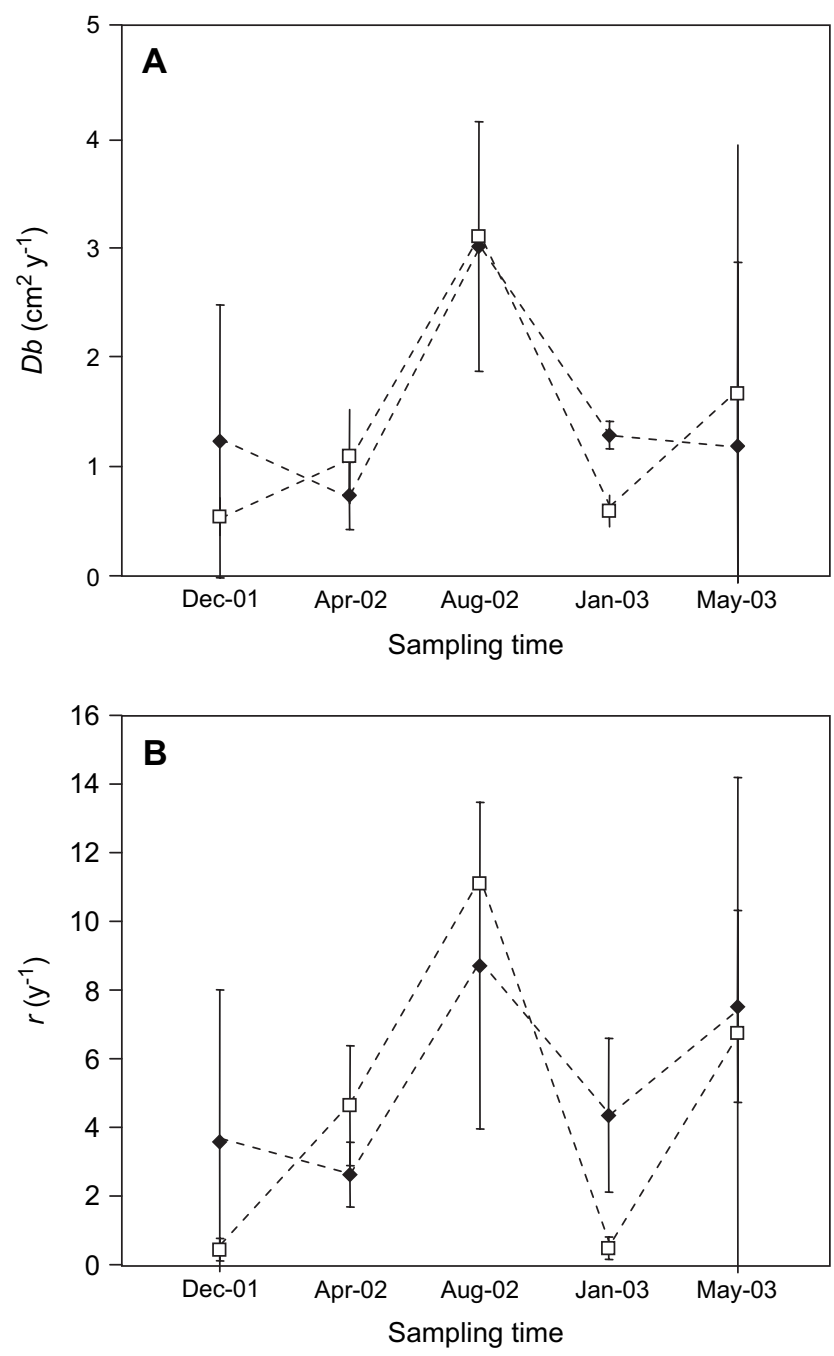

Fig. 11. Sediment reworking in sediments from the central part of the Thau Lagoon (C4: full symbol) and near the shellfish farming zone (C5: open symbol), for the different sampling times. A: biodiffusion coefficient $\left(D_{\mathrm{b}}\right)$; and B: biotransport coefficient $(r)$. Values are mean $\pm \mathrm{SD}(n=3)$.

Cluster analyses (Fig. 5) performed show that from the qualitative and quantitative points of view, two distinct populations are present at stations $\mathrm{C} 4$ and $\mathrm{C} 5$.

Notably, at station C5, populations are affected by the proximity of shellfish tables, an area which induces an organic enrichment characterized by the presence of Capitella capitata, Scolelepis fuliginosa and Nereis caudata (Deslous-Paoli et al., 1998).

Analyses also demonstrate the relative stability of the populations with time at station $\mathrm{C} 4$. On the other hand, the temporal changes are more pronounced at station $\mathrm{C} 5$. The factorial correspondence analyses (FCA) clearly indicate that the qualitative and quantitative changes in the population compositions are linked to different factors taking place both at a large (lagoon) or local (station) scale.

From December 2001 to May 2003, at both stations, a general trend was observed: a change in trophic structure particularly marked by the transition from a mixture of surface and sub-surface deposit feeder species to a supremacy of surface deposit feeder species. Changes in trophic structure of the community with time, and especially the development of surface feeders generally correlate with surface organic enrichment (Pearson and Rosenberg, 1978; Desrosiers et al., 2000).

Regarding local factors, the factorial correspondence analyses performed (FCA) demonstrate the influence of variations in granulometry (at both stations) and of a local disturbance (May 2003, at station C5) on population temporal changes. The variations in granulometry can be driven by hydrodynamic factors, i.e., strong wind events. The local disturbance at station $\mathrm{C} 5$ is characterized by the recent installation of juvenile Capitella capitata which suggests strong mortality of the previous population assemblage. In May 2003, the oxygen depletion (Table 2) related to sediment organic matter content and high temperatures may have induced this mortality. According to porewater profiles, in this period, station C5 sediments presented a hypereutrophic status (Mesnage et al., pers. comm.).

\subsection{Sediment reworking}

Although species composition differed between the two stations, results have shown that sediment mixing affected by benthic organisms was similar at both sites for both continuous and non-continuous transport. This can be explained by taking into account bioturbation functional groups (i.e., gallerydiffusors, biodiffusors, upward conveyors, downward conveyors and regenerators; Gardner et al., 1987; François et al., 1997; François et al., 2002). Bray-Curtis similarity index based on a bioturbation group matrix shows that the functional composition was generally similar between the two stations (Fig. 12).

Table 2

Oxygen parameters at the water-sediment interface and bottom water temperature in the central part of the Thau Lagoon (C4) and near the shellfish farming zone (C5), for the different sampling times. Values are mean $\pm \mathrm{SD}$ for the oxygen penetration depth

\begin{tabular}{|c|c|c|c|c|}
\hline & Replicates & $\begin{array}{l}\text { Oxygen } \\
\text { penetration } \\
\text { depth } \\
(\mathrm{mm})\end{array}$ & $\begin{array}{l}\text { Oxygen } \\
\text { flux } \\
\left(\mathrm{mmol} \mathrm{m}^{-2} \mathrm{~d}^{-1}\right)\end{array}$ & $\begin{array}{l}\text { Bottom water } \\
\text { temperature } \\
\left({ }^{\circ} \mathrm{C}\right)\end{array}$ \\
\hline \multicolumn{5}{|c|}{ December 2001} \\
\hline Station C4 & $n=8$ & $3.2 \pm 0.8$ & 15.5 & 9.6 \\
\hline Station C5 & $n=7$ & $1.7 \pm 1.0$ & 36.8 & 9.6 \\
\hline \multicolumn{5}{|l|}{ April 2002} \\
\hline Station $\mathrm{C} 4$ & $n=6$ & $3.9 \pm 0.9$ & 11.0 & 13 \\
\hline Station C5 & $n=11$ & $1.4 \pm 0.4$ & 39.7 & 13 \\
\hline \multicolumn{5}{|l|}{ August 2002} \\
\hline Station $\mathrm{C} 4$ & $n=2$ & $1.2 \pm 0.0$ & 29.6 & 23 \\
\hline Station C5 & $n=12$ & $0.7 \pm 0.2$ & 72.6 & 23 \\
\hline \multicolumn{5}{|l|}{ January 2003} \\
\hline Station C4 & $n=3$ & - & 8.6 & 8.5 \\
\hline Station C5 & $n=13$ & $1.3 \pm 0.4$ & 52.2 & 8.5 \\
\hline \multicolumn{5}{|l|}{ May 2003} \\
\hline Station C4 & $n=7$ & $0.9 \pm 0.2$ & 30.7 & 18 \\
\hline Station C5 & $n=16$ & $0.8 \pm 0.3$ & 87.7 & 18 \\
\hline
\end{tabular}




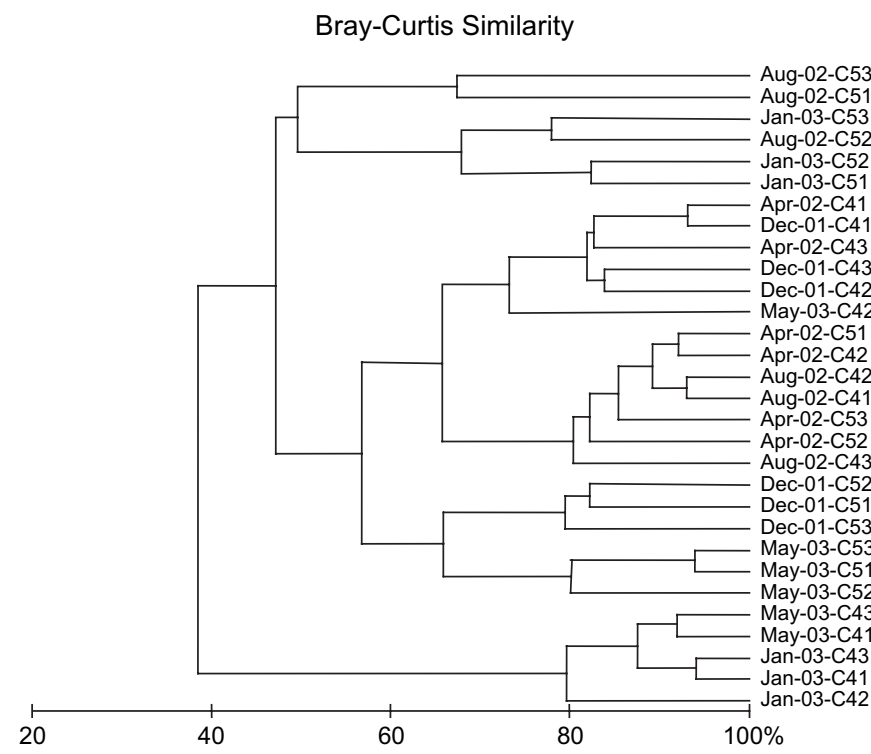

Fig. 12. Dendrogram of Thau samples clustered with Bray-Curtis index (based on a bioturbation group matrix) and group average sorting. Sample code: sampling time, station name and replicate number, e.g., December 2001-C41 means replicate 1 of the station 4 (central part of the Thau Lagoon) in December 2001

This was not the case, however, in January 2003 and May 2003, where the comparison between stations C4 and C5 either revealed that they came out with different mixing coefficients or showed a very high variability of sediment reworking activity, respectively (Fig. 11). In January 2003, the biodiffusors were the dominant group in station $\mathrm{C} 4$ while gallery-diffusors dominated in station C5 (Table 3). The same distribution was observed in May 2003, except for one sample from station C4 in which gallery-diffusor organisms dominated (45\%). This heterogeneity between the replicates could explain the observed variability in sediment reworking.

Sediment mixing analysis also demonstrated, for both stations, changes in reworking intensity with time. These differences are mainly due to the increase in reworking observed in August 2002, as also recorded by Schmidt et al. (2007) using ${ }^{7} \mathrm{Be}$ and ${ }^{234} \mathrm{Th}$ tracers. At that period, reduced oxygen availability in the sediments linked to higher seasonal temperatures
(Table 2), may have contributed to more intensive bioirrigation activity of the organisms in order to enhance oxygen penetration to deeper sediments (Aller, 1982; Kristensen, 1983; Ouellette et al., 2004). This water circulation induced by the organism is known to destabilize surface particles and carry them to the bottom of the burrow (François et al., 2002). This increase in sediment reworking was, however, not measured in May 2003 while the temperatures and oxygen conditions were close than those of August 2002. If the juvenile state of the community in May 2003 at station C5 (near the shellfish farming zone) could explain the low mixing rate compared to August 2002, this was not the case for station C4 (in the central part of the Thau Lagoon). Again, the difference between these two sampling times can be explained by the bioturbation functional composition of the communities with an increase of biodiffusors and a decrease of gallery-diffusors in May 2003 with regard to August 2002 (Table 3).

This result emphasizes the importance of the functional biodiversity of the communities in the dynamics of sediment mixing as for the solute exchanges at the water-sediment interface (Emmerson et al., 2001).

In conclusion, our results have demonstrated that functional groups assemblage in community and environmental factors play a major role in the intensity of sediment mixing.

Specifically, within the framework of the Microbent program, our work has provided evidence, in the Thau Lagoon, of a generally similar potentiality of contaminant reworking within and outside the farming zones. At some periods, however, sediment mixing intensity may differ between the studied stations. Sediment reworking has also been found to be variable with time, showing, for instance, an increase of intensity in summer. These changes in sediment reworking intensity suggest potentially different redistribution, bioaccumulation and chemical fate (e.g., speciation) of deposited contaminants.

\section{Acknowledgements}

We thank J.-L. Guillou and the crew of the R/V Chlamys for their assistance at sea and the different divers, especially the COM Diving team (R. Graille, B. de Ligondès, F. Zuberer)

Table 3

Percentages of bioturbation functional groups (see Gérino et al., 2004) in each core sampling in the central part of the Thau Lagoon (station C4) and near the shellfish farming zone (station C5), for the different sampling times

\begin{tabular}{|c|c|c|c|c|c|c|c|c|c|c|c|c|c|c|c|}
\hline \multirow[b]{2}{*}{ Station C4 } & \multicolumn{3}{|c|}{ December 2001} & \multicolumn{3}{|c|}{ April 2002} & \multicolumn{3}{|c|}{ August 2002} & \multicolumn{3}{|c|}{ January 2003} & \multicolumn{3}{|c|}{ May 2003} \\
\hline & $\mathrm{C} 41$ & $\mathrm{C} 42$ & $\mathrm{C} 43$ & $\mathrm{C} 41$ & $\mathrm{C} 42$ & $\mathrm{C} 43$ & $\mathrm{C} 41$ & $\mathrm{C} 42$ & $\mathrm{C} 43$ & $\mathrm{C} 41$ & $\mathrm{C} 42$ & $\mathrm{C} 43$ & $\mathrm{C} 41$ & $\mathrm{C} 42$ & $\mathrm{C} 43$ \\
\hline Biodiffusors & 53.1 & 36.1 & 50 & 52.1 & 44.9 & 39.4 & 50.6 & 47.1 & 41.1 & 68.8 & 82.6 & 75 & 73.3 & 22 & 79.85 \\
\hline Downward conveyors & 5.5 & 9 & 8.2 & 5 & 2.6 & 3.9 & 8.3 & 11.7 & 19.2 & 11.9 & 4.3 & 7.1 & 6 & 17.8 & 5.3 \\
\hline Upward conveyors & 14.1 & 24 & 17.4 & 10.7 & 9.3 & 10.2 & 6.6 & 6.7 & 0.9 & 4.8 & 1.6 & 3.6 & 2.1 & 15.3 & 3 \\
\hline Gallery-diffusors & 27.3 & 29.3 & 24.5 & 32.1 & 42.7 & 44.9 & 34.4 & 34.1 & 38.8 & 14.5 & 11.5 & 14.3 & 18.4 & 44.9 & 11.7 \\
\hline Undetermined & 0 & 1.5 & 0 & 0 & 0.4 & 1.6 & 0 & 0.5 & 0 & 0 & 0 & 0 & 0.3 & 0 & 0.3 \\
\hline Station C5 & $\mathrm{C} 51$ & C52 & $\mathrm{C} 53$ & $\mathrm{C} 51$ & $\mathrm{C} 52$ & C53 & $\mathrm{C} 51$ & C52 & $\mathrm{C} 53$ & $\mathrm{C} 51$ & $\mathrm{C} 52$ & $\mathrm{C} 53$ & $\mathrm{C} 51$ & $\mathrm{C} 52$ & $\mathrm{C} 53$ \\
\hline Biodiffusors & 12.4 & 9.5 & 1 & 44.2 & 50.7 & 50.2 & 55 & 44.4 & 75.7 & 33.3 & 30.4 & 31.3 & 27.3 & 18.5 & 24.3 \\
\hline Downward conveyors & 0 & 2.6 & 2 & 4.9 & 4.2 & 5.68 & 18.3 & 11.1 & 13.6 & 0 & 2.5 & 3.1 & 0 & 0 & 0 \\
\hline Upward conveyors & 11.1 & 23.3 & 8.1 & 14.3 & 9.7 & 17.2 & 6.7 & 2.2 & 1 & 3.5 & 22.8 & 0 & 0.8 & 0 & 0 \\
\hline Gallery-diffusors & 76.5 & 64.7 & 87.9 & 36.2 & 35.1 & 25.1 & 20 & 42.2 & 9.7 & 63.2 & 44.3 & 65.6 & 71.9 & 81.5 & 73.6 \\
\hline Undetermined & 0 & 0 & 1 & 0.55 & 0.3 & 1.9 & 0 & 0 & 0.00 & 0 & 0 & 0 & 0 & 0 & 2.1 \\
\hline
\end{tabular}


for their skilled work in the field, both of which were essential to the success of field operations. The IFREMER Station de Sète is acknowledged for its logistical support through lab space and the research boat. Thanks are also due to the three anonymous referees whose comments have significantly helped to improve the manuscript, and to Michael Paul for reading the manuscript. This research was supported by the PNEC/ART1/MICROBENT program and the EU commission (STREP COBO; contract number GOCE-CT-2003-505564). Nereis Park contribution number 11.

\section{References}

Aller, R.C., 1982. The effects of macrobenthos on chemical properties of marine sediment and overlying water. In: McCall, P.L., Tevesz, M.J.S. (Eds.), Animal-Sediment Relations. Plenum Press, New York, USA, pp. 53-102.

Benzecri, J.P., et al., 1973. L'analyse de données. Tome II: L'analyse de correspondance. Dunod, Paris, 619 pp.

Berner, R.A., 1980. Early Diagenesis: A Theoretical Approach. Princeton University Press, Princeton, New Jersey, 256 pp.

Blake, J.A., Grassle, J.F., 1994. Benthic community structure on the U.S South Atlantic slope off the Carolinas: spatial heterogeneity in a currentdominated system. Deep Sea Research Part II 41, 835-874.

Boudreau, B.P., 1986. Mathematics of tracer mixing in sediments: II. Nonlocal mixing and biological conveyor-belt phenomena. American Journal of Science 286, 199-238.

Bray, J.R., Curtis, J.T., 1957. An ordination of the upland forest communities of Southern Wisconsin. Ecological Monograph 27, 325-349.

Clarke, K.R., Warwick, R.M., 2001. Changes on Marine Communities: An Approach to Statistical Analysis and Interpretation, second ed. PRIMERE, Plymouth, UK.

Coull, B.C., 1977. Ecology of Marine Benthos. In: The Belle W. Baruch Library in Marine Science, $\mathrm{N}^{\circ}$ 6. University of South Carolina Press, $467 \mathrm{pp}$.

Dedieu, K., Rabouille, C., Mesnage, V., Ogier, S., 2007. Benthic $\mathrm{O}_{2}$ distribution and dynamics in a Mediterranean lagoon (Thau, France): An in situ microelectrode study. Estuarine, Coastal and Shelf Science 72 (3), 393-405.

Deslous-Paoli, J.-M., Souchu, P., Mazouni, N., Jujge, C., Dagault, F., 1998 Relations milieu-ressources: impact de la conchyliculture sur un environnement lagunaire méditérannéen (Thau). Oceanologica Acta 21, 831-843.

Desrosiers, G., Savenkoff, C., Olivier, M., Stora, G., Kuniper, J., Caron, A., Gagné, J.-P., Mulsow, M., Legendre, L., Roy, S., Grehan, A., Scaps, P., Silverberg, N., Klein, B., Tremblay, J.-E., Therriault, J.-C., 2000. Trophic structure of macrobenthos in the Gulf of St. Lawrence and the Scotian Shelf. Deep Sea Research Part II 47, 663-697.

Emmerson, M.C., Solan, M., Emes, C., Paterson, D.M., Raffaelli, D., 2001. Consistent patterns and the idiosyncratic effects of biodiversity in marine ecosystems. Nature 411, 73-77.

Fauchald, K., Jumars, P.A., 1979. The diet of worms: a study of polychaete feeding guilds. Oceanography and Marine Biology, An Annual Review 17, 193-284.

François, F., Poggiale, J.-C., Durbec, J.-P., Stora, G., 1997. A new approach for the modelling of sediment reworking induced by a macrobenthic community. Acta Biotheoritica 45, 295-319.

François, F., Dalègre, K., Gilbert, F., Stora, G., 1999. Specific variability within functional groups. Study of the sediment reworking of two Veneridae bivalves, Ruditapes decussatus and Venerupis aurea. Comptes Rendus de 1'Académie des Sciences - Series III - Sciences de la Vie 322, 339-345

François, F., Gérino, M., Stora, G., Durbec, J.-P., Poggiale, J.-C., 2002. Functional approach to sediment reworking by gallery-forming macrobenthic organisms: modelling and application with the polychaete Nereis diversicolor. Marine Ecology Progress Series 229, 127-136.

Gangnery, A., Chabirand, J.-M., Lagarde, F., Le Gall, P., Oheix, J., Bacher, C. Buestel, D., 2003. Growth model of the Pacific oyster, Crassostrea gigas, cultured in Thau Lagoon (Méditerranée, France). Aquaculture 215, 267-290.
Gardner, L.R., Sharma, P., Moore, W.S., 1987. A regeneration model for the effect of bioturbation by fiddler crabs on ${ }^{210} \mathrm{~Pb}$ profiles in salt marsh sediments. Journal of Environmental Radioactivity 5, 25-36.

Gérino, M., 1990. The effects of bioturbation on particule redistribution in Mediterranean coastal sediment. Preliminary results. Hydrobiologia 207, $251-258$.

Gérino, M., Stora, G., Poydenot, F., Bourcier, M., 1995. Benthic fauna and bioturbation on the Mediterranean continental slope: Toulon Canyon. Continental Shelf Research 15, 1483-1496.

Gérino, M., Stora, G., Weber, O., 1999. Evidence of bioturbation in the Cap-Ferret Canyon in the deep northeastern Atlantic. Deep Sea Research Part II: Topical Studies in Oceanography 46, 2289-2307.

Gérino, M., Stora, G., François-Carcaillet, F., Gilbert, F., Poggiale, J.-C., Mermillot-Blondin, F., Desrosiers, G., Vervier, P., 2004. Macro-invertebrates functional groups in freshwater and marine sediments: a common mechanistic classification. Vie et Milieu 53, 221-232.

Gilbert, F., Stora, G., Bertrand, J.-C., 1996. In situ bioturbation and hydrocarbon fate in an experimental contaminated Mediterranean coastal ecosystem. Chemosphere 33, 1449-1458.

Gilbert, F., Hulth, S., Strömberg, N., Ringdahl, K., Poggiale, J.-C., 2003. 2-D optical quantification of particle reworking activities in surface marine sediments. Journal of Experimental Marine Biology and Ecology 285/286, $251-263$.

Guelorget, O., Perthuisot, J.-P., Lamy, N., Lefebvre, A., 1994. Structure et organisation de l'Etang de Thau d'après la faune benthique (macrofaune, méiofaune). Relations avec le confinement. Oceanologica Acta 17, 105-114.

Hamon, P.Y., Tournier, H., 1981. Estimation de la biomasse en culture dans l'Etang de Thau. Science de la Pêche 313, 1-23.

Kristensen, E., 1983. Ventilation and oxygen uptake by three species of Nereis (Annelida: Polychaeta). II. Effects of temperature and salinity changes. Marine Ecology Progress Series 12, 299-306.

Lee, H., Swartz, R.C., 1980. Biological processes affecting the distribution of pollutants in marine sediments. Part II. Biodeposition and bioturbation. In: Baker, R.A. (Ed.), Contaminants and Sediments, 2. Ann Arbor Science Publishing, Ann Arbor, USA, pp. 555-606.

Meysman, F.J.R., Boudreau, B.P., Middleburg, J.J., 2003. Relations between local, nonlocal, discrete and continuous models of bioturbation. Journal of Marine Research 61, 391-410.

Mortimer, R.J.G., Davey, J.T., Krom, M.D., Watson, P.G., Frickers, P.E., Clifton, R.J., 1999. The effect of macrofauna on porewater profiles and fluxes in the intertidal zone of the Humber estuary. Estuarine, Costal and Shelf Science 48, 683-699.

Orvain, F., Sauriau, P.G., 2002. Environmental and behavioural factors affecting activity in the intertidal gastropod Hydrobia ulvae. Journal of Experimental Marine Biology and Ecology 272, 191-216.

Ouellette, D., Desrosiers, G., Gagné, J.P., Gilbert, F., Poggiale, J.C., Blier, P.U., Stora, G., 2004. Effects of temperature on in vitro sediment reworking processes by a gallery biodiffusor, the polychaete Neanthes virens. Marine Ecology Progress Series 266, 185-193, 30.

Pearson, T.H., Rosenberg, R., 1978. Macrobenthic succession in relation to organic enrichment and pollution of the marine environment. Oceanography and Marine Biology, An Annual Review 16, 229-311.

Pérès, J.M., Picard, J., 1964. Nouveau manuel de bionomie benthique de la mer Méditerranée. Recueil des Travaux de la Station Marine d'Endoume 31, 5-137.

Pérès, J.M., 1982. Major benthic assemblages. In: Kinne, O. (Ed.), Marine Ecology, 8. John Wiley, Chichester, Great Britain, pp. 373-552.

Picard, J., 1965. Recherches qualitatives sur les biocénoses marines des substrats meubles dragables de la région marseillaise. Recueil des Travaux de la Station Marine d'Endoume 52, 1-160.

Sanders, H.L., Grassle, J.F., Hampson, G.R., Morse, L.S., Garnier-Price, S., Jones, C.C., 1980. Anatomy of an oil spill: long term effects from the grounding of the barge Florida off west Falmouth Massachusetts. Journal of Marine Research 38 (2), 265-380.

Sandnes, J., Forbes, T., Hansen, R., Sandnes, B., 2000. Influence of particle type and faunal activity on mixing of di (2-ethylhexyl)phthalate (DEHP) in natural sediments. Marine Ecology Progress Series 197, 151-167. 
Schmidt, S., Jouanneau, J.-M., Weber, O., Lecroart, P., Radakovitch, O., Gilbert, F., Jezequel, D., 2007. Sedimentary processes in the Thau Lagoon (France): from seasonal to century time scales. Estuarine, Coastal and Shelf Science 72 (3), 534-542.

Stoeck, T., Kröncke, I., 2001. Influence of particle mixing on vertical profiles of chlorophyll $a$ and bacterial biomass in sediments of the German Bight, Oyster Ground and Dogger bank (North Sea). Estuarine, Coastal and Shelf Science 52, 783-795.

Soletchnik, P., Huvet, A., Le Moine, O., Razet, D., Geairon, P., Faury, N., Goulletquer, P., Boudry, P., 2002. A comparative field study of growth, survival and reproduction of Crassostrea gigas, C. angulata and their hybrids. Aquatic Living Resources 15, 243-250.
Sorensen, T., 1948. A method of establishing groups of equal amplitude in plant sociology based on similarity of species content and its application to analysis of the vegetation on Danish commons. Biologisk Skrifter udgivet of det Kongelige dauske Videnskarbernes selskab 5, 1-34.

Vincent, B., 1981. Profondeur, vase et courant, facteurs de micro-répartition transversale du benthos dans l'estuaire d'eau douce du Saint-Laurent (Québec). Canadian Journal of Zoology 59, 2297-2305.

Woolfe, K.J., Michibayashi, K., 1995. "BASIC" entropy grouping of laserderived grain-size data: an example from the Great Barrier Reef. Computers \& Geosciences 21, 447-462.

Zar, J.H., 1998. Biostatical Analysis. Prentice-Hall, Upper Saddle River, New Jersey, 664 pp. 